
ИЗВЕСТИЯ НАЦИОНАЛЬНОЙ АКАДЕМИИ НАУК АРМЕНИИ

Uthuukpluu

68, №3, 2015

Механика

УДК 539.3

\title{
STABILITY OF A BEAM WITH PERIODIC SUPPORTS
}

\section{Avetisyan A.S. , Belubekyan M.V., Ghazaryan K.B.}

Kew words: Floquet theory, inhomogeneous beam, stability, periodic supports

Ключевые слова: Теория Флоке, неоднородная балка, устойчивость, периодические опоры.

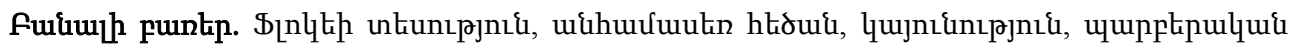
htiqupuiqutip:

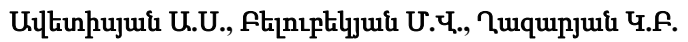

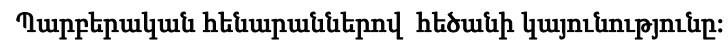

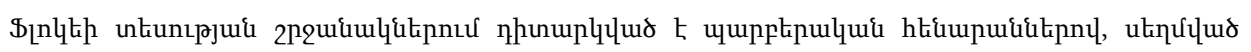

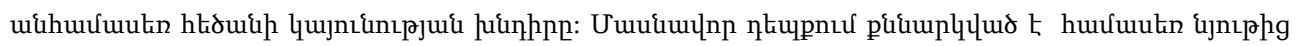

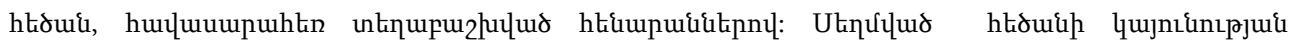

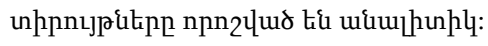

\section{Аветисян А.С., Белубекян М.В., Казарян К.Б. \\ Устойчивость балки с периодическими опорами}

В рамках теории Флоке рассмотрена задача устойчивости сжатого неоднородного стержня с периодическими опорами. Частный случай однородного стержня с равномерно распределёнными опорами изучен; области устойчивости сжатой балки определены аналитически.

In terms of the Floquet theory the stability problem is considered for a compressed inhomogeneous beam with periodic supports. The special case of homogeneous beam with periodic supports of the uniform span is studied, the stability and instability regions of the compressed force values are determined analytically.

Introduction. Problems of vibrations and stability of beams (plates, shells) and beam structures are very similar. Mathematically, in many cases they lead to the same eigenvalue boundary problems. However, there are cases where the analogy breaks down. A great number of papers is devoted to the analysis of wave propagation in periodic structures that consist of a number of elastic structural different elements (commonly with large contrast in elastic properties and densities ) joined together in periodic manner to form the whole structure. [1-9]. Interest to these problems is due to the existence of complete elastic band gaps within which all vibrations are forbidden.

The gap band structure of flexural bending wave in the periodic beam and beam on elastic foundation are studied in [5-7 ]. Propagation of bending waves in a homogeneous beam with periodically interfaces of incomplete elastic contacts is considered in [8,9 ]. What is an analogy with the stability problems of such beams and what is the difference? It is clear that the problem of stability of an infinitely long, non-uniform beam does not 
make sense. The problem of stability of a beam with periodically inhomogeneous periodic structure of supports should be similar to the vibration problem of the same beam.

1.Statement of the problem. We consider an infinite one-dimensional periodically composed beam with the unit cell of a period $d=l_{1}+l_{2}$ consisting of two piecewisehomogeneous parts having different bending rigidities. The joints between beam different parts are simply supported ones. (Fig 1.) The beam is compressed by the axial force $P$ applied at beam infinity edges.

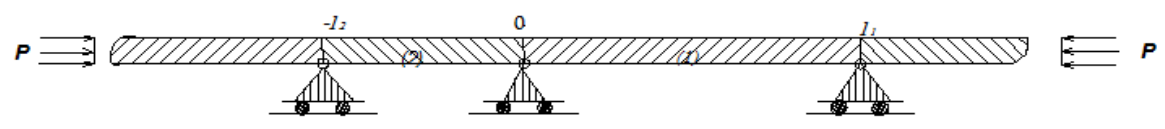

Fig.1. Piecewise compressed beam with periodic supports

The beam stability equations can be written as $[10,11]$

$\frac{d^{4} w_{i}}{d x^{4}}+\alpha_{i}^{2} \frac{d^{2} w_{i}}{d x^{2}}=0, \quad \alpha_{i}^{2}=\frac{P}{E_{i} J_{i}}$

where superscripts $i=1, i=2$ show that the functions belong to beam unit parts $0<x \leq l_{1}$ and $-l_{2} \leq x<0$, respectively, $w_{i}(x)$ are the transverse displacements, $P$ is the axial compressive force applied at the infinity edges of the compound beam structure, $E_{i} J_{i}$ - are the bending rigidities of unit beam piecewise-homogeneous parts.

The following contact conditions at point $x=0$ should be satisfied

$w_{1}=w_{2}=0, \frac{d w_{1}}{d x}=\frac{d w_{2}}{d x}, \quad \frac{d^{2} w_{1}}{d x^{2}}=\beta^{2} \frac{d^{2} w_{2}}{d x^{2}}$,

Here $\beta=\sqrt{\left(E_{2} J_{2}\right) /\left(E_{1} J_{1}\right)}$.

By analogy with the vibration problems of a periodic inhomogeneous beam the Floquet boundary conditions of quasi-periodicity can be taken as

$w_{1}\left(l_{1}\right)=0, \quad w_{2}\left(-l_{2}\right)=0$,

$\left.\lambda \frac{d w_{1}}{d x}\right|_{x=l_{1}}=\left.\frac{d w_{2}}{d x}\right|_{x=-l_{2}},\left.\quad \lambda \frac{d^{2} w_{1}}{d x^{2}}\right|_{x=l_{1}}=\left.\beta^{2} \frac{d^{2} w_{2}}{d x^{2}}\right|_{x=-l_{2}}$ 
$\lambda=\exp \left[i k\left(l_{1}+l_{2}\right)\right], k$ is the Floquet number.

2. Solution of the problem. Solution of eq.(1.1) has the form

$w_{i}(x)=A_{i}+B_{i} x+C_{i} \sin \left(\alpha_{i} x\right)+D_{i} \cos \left(\alpha_{i} x\right) ; \quad i=1 ; 2$

where $A_{i}, B_{i}, C_{i}, D_{i}$ are arbitrary constants,

Substituting these solutions into the contact conditions (1.2) and Floquet quasi-periodicity boundary conditions (1.3) a simultaneous set of equations with respect to the arbitrary $A_{i}, B_{i}, C_{i}, D_{i}$ are obtained . Equating the determinant of the simultaneous set of equations to zero will produce the equation

$$
F(P) \cos \left[k\left(l_{1}+l_{2}\right)\right]-S(P)=0
$$

where

$$
\begin{aligned}
& S(P)=l_{1} l_{2} \alpha_{1}^{2} \alpha_{2}^{2} \beta^{2} \cos \left(l_{1} \alpha_{1}\right) \cos \left(l_{2} \alpha_{2}\right)+l_{1} \alpha_{1}^{3} \sin \left(l_{1} \alpha_{1}\right)+l_{2} \alpha_{2}^{3} \beta^{4} \sin \left(l_{2} \alpha_{2}\right)- \\
& -\left(l_{1} \alpha_{1}^{2}+l_{2} \alpha_{2}^{2} \beta^{2}\right)\left[\alpha_{1} \cos \left(l_{2} \alpha_{2}\right) \sin \left[l_{1} \alpha_{1}\right]+\alpha_{2} \beta^{2} \cos \left(l_{1} \alpha_{1}\right) \sin \left(l_{2} \alpha_{2}\right)\right]+ \\
& +\alpha_{1} \alpha_{2}\left(\beta^{2}-\frac{l_{1} l_{2}\left(\alpha_{1}^{2}+\alpha_{2}^{2} \beta^{4}\right)}{2}\right) \sin \left(l_{1} \alpha_{1}\right) \sin \left(l_{2} \alpha_{2}\right) \\
& F(P)=\alpha_{1} \alpha_{2} \beta^{2}\left[l_{1} \alpha_{1}-\sin \left(l_{1} \alpha_{1}\right)\right]\left[l_{2} \alpha_{2}-\sin \left(l_{2} \alpha_{2}\right)\right]
\end{aligned}
$$

For given values of the axial force $P$ Eq. (2.2) determines the Floquet number $k$. The regions of $P$ where

$\left|\cos \left[k\left(l_{1}+l_{2}\right)\right]\right|>1 \quad$ (values of $k$ are complex ) correspond to beam stability regions .

The regions of $P$ where $\left|\cos \left[k\left(l_{1}+l_{2}\right)\right]\right| \leq 1$ ( values of $k$ are real ) correspond to beam instability regions.

3. Special cases of a beam and supports structure. Let us now consider the homogeneous beam of the uniform span of periodic supports

$l_{1}=l_{2}=l, \quad E_{1} J_{1}=E_{2} J_{2}, \quad \alpha_{1}=\alpha_{2}=\alpha$

In this case instead of eq. (2.2) we have 


$$
\cos (2 k l)=\frac{\left[1-\left(1-2 \alpha^{2} l^{2}\right) \cos (2 \alpha l)+4 \alpha l \cdot \sin (\alpha l)-4 \alpha l \cdot \sin (2 \alpha l)\right]}{2(\sin (\alpha l)-\alpha l)^{2}}
$$

which can be transformed to the following eqution

$\cos ^{2}(k l)=F^{2}(\alpha l)$

$F(\alpha l)=\frac{\alpha l \cdot \cos (\alpha l)-\sin (\alpha l)}{\alpha l-\sin (\alpha l)}$

Since for any values of $\alpha l$ the function $F(\alpha l) \leq 1$ and $F(0)=-2$, the regions of $\alpha l$ where $F(\alpha l)<-1\left(F^{2}(\alpha l)>1\right)$ will correspond to beam stability regions, for all values of $\alpha l$ outside of these regions the beam becomes instable.

The boundaries of stability and instability regions are determined from equation

$$
F(\alpha l)=-1
$$

Equation (3.4) can be transformed into

$$
\cos (\alpha l / 2) \cdot(\alpha l \cdot \cos (\alpha l / 2)-2 \cdot \sin (\alpha l / 2))=0
$$

from which follows the simultaneous set of equations

$$
\cos (\alpha l / 2)=0, \quad \operatorname{tg}(\alpha l / 2)=\alpha l / 2
$$

The roots of the equations (3.6)

$$
\begin{aligned}
& (\alpha l)_{n}^{(1)}=(2 n-1) \pi ; \\
& (\alpha l)_{0}^{(2)}=0,(\alpha l)_{n}^{(2)}=(2 n+1) \pi-\varepsilon_{n} \quad n=1 ; 2 \ldots \ldots
\end{aligned}
$$

define the boundaries of beam stability (instability) regions.

In (3.7) $\varepsilon_{n}<<\pi, \quad \varepsilon_{n+1}<\varepsilon_{n}, \quad \varepsilon_{n} \rightarrow 0, \quad \varepsilon_{1}=0.4417$

Thus. the stability intervals of axial force $P(\alpha l)$ can be found as

$$
\alpha l \in(0, \pi) \cup \bigcup_{n=1}^{\infty}\left((2 n+1) \pi-\varepsilon_{n},(2 n+1) \pi\right),
$$

In these intervals equation (3.3) has no roots corresponding to real Floquet number $k$.

It is worth to note that the lengths of second and consequent intervals are very small, practically reach to zero for $n \geq 5$.

The values of $\alpha l$ which do not belong to (3.8) intervals correspond to critical values of axial force $P$ under which the beam structure is unstable. 
Let us now consider the beam structure when the rigidities of materials of periodic parts are significantly different. When the beam parts with index $i=2$ are substantially rigid as compared with other parts with index $i=1 \quad \alpha_{2} l_{2} \ll 1$, taking in (2.3) $\sin \left(l_{2} \alpha_{2}\right) \approx l_{2} \alpha_{2}, \cos \left(l_{2} \alpha_{2}\right) \approx 1 \quad$ we come to the equation which does not depend from Floquet number $k$

$$
2\left(\cos \left(\alpha_{1} l_{1}\right)-1\right)+\alpha_{1} l_{1} \cdot \sin \left(\alpha_{1} l_{1}\right)=0
$$

The equation (3.9) is convenient to transform to the following form

$$
\sin \left(\alpha_{1} l_{1} / 2\right)\left[\alpha_{1} l_{1} \cos \left(\alpha_{1} l_{1} / 2\right)-2 \alpha_{1} l_{1} \cdot \sin \left(\alpha_{1} l_{1} / 2\right)\right]=0
$$

From (3.10) it follows that minimal critical value $\left(\alpha_{1} l_{1}\right)^{*}$ is the first root of the equation

$$
\begin{aligned}
& \operatorname{tang}\left(\frac{\alpha_{1} l_{1}}{2}\right)=\frac{2}{\alpha_{1} l_{1}} ; \\
& \left(\alpha_{1} l_{1}\right)^{*}=1.721
\end{aligned}
$$

\section{Conclusion}

In the framework of the Floquet theory the analog set between stability and vibration problems of inhomogeneous elastic beam periodic structure. The infinite compressed beam is considered consisting with periodic piecewise-homogeneous parts of different bending rigidities. The periodic joints between beam different parts are simply supported ones. The equation relate to Floquet number and compressed force is obtained which enables to define the stability and instability regions of the compressed force values. The special case of homogeneous compressed beam with periodic supports of uniform span is discussed in detail. The beam stability and instability regions of the compressed force are determined analytically. The minimal value of critical force is defined for beam when the rigidities of materials of periodic parts are significantly different.

\section{Acknowledgment}

This research was supported by State Committee of Science of Armenia Grant No. SCS 13-2C005. 


\section{References}

1. E.H. Lee, A survey of variational methods for elastic wave propagation analysis in composites with periodic structures, in Dynamics of Composite Materials, E.H. Lee, ed., ASME, New York, 1972, pp. 122-138.

2. E.H. Lee and W. H. Yang, On waves in composite materials with periodic structure. //SIAM Journal on Applied Mathematics., 25 (1973), pp. 492-499.

3. Mingrong Shen, Wenwu Cao, Acoustic bandgap formation in a periodic structure with multilayer unit cells. //Journal Phys. D: Appl. Phys.33, (2000), p.1150-1154.

4. A.Velo, E. Bruder, N. Rodriguez, G. Gazonas, E. Bruder, Recursive Dispersion Relations in One-Dimensional Periodic Elastic Media. //SIAM Journal on Applied Mathematics, Vol.69, No.3, pp.670-689, (2008).

5. V.G. Papanicolaou. The Floquet Theory of the Periodic Euler Bernoulli Equation, journal of differential equations 150, 24-41 (1998),

6. V.G. Papanicolaou, The Spectral Theory of the Vibrating Periodic Beam, Comm. Math.Phys. 170 (1995), 359-373.

7. S. Adams, R. Craster, S. Guenneau, Bloch waves in periodic multi-layered acoustic waveguides, Proceedings Royal Society London A 464 (2008), p.2669-2692.

8. Казарян К.Б., Казарян Р.А. Изгибные волны Флоке в пластинке-полосе с периодической структурой интерфейсов. Проблемы динамики взаимодействия деформируемых сред//Труды VII Международной конференции, ГорисСтепанакерт. 2011. С.194-199.

9. Белубекян М.В., Казарян К.Б., Казарян Р.А. Изгибные волны Флоке в балке периодической структуры неполного упругого контакта. Проблемы динамики взаимодействия деформируемых сред. // Труды VIII Международной конференции, Горис-Степанакерт, 2014. С.93-97.

10. Алфутов Н.А. Основы расчёта на устойчивость упругих систем. М.: Машиностроение, 1991. 336с.

11. Вольмир А.С. Устойчивость деформируемых систем. М.: Наука, 1967. 984c.

\section{Сведения об авторах:}

Аветисян Ара Сергеевич - Чл.-корр. НАН Армении, доктор физ.-мат.наук, Институт механики НАН Армении.

Адрес: 0019, Ереван, пр. Маршала Баграмяна, 24/2, тел.: (+37493)00-44-55.

E-mail: ara.serg.avetisyan@gmail.com

Белубекян Мелс Вагаршакович - кандидат физ.-мат.наук, профессор, главный научный сотрудник Института механики НАН РА, Ереван, Армения. Тел.: (+374 10) 52-15-03; (+374 10) 58-00-96

E-mail: mbelubekyan@yahoo.com

Казарян Карен Багратович - доктор физ.-мат.наук, профессор, главный научный сотрудник Института механики НАН РА. Тел.: (374 10) 2273 95, (374 955) 227395. E-mail: ghkarren@gmail.com 